\title{
SOX6 wt Allele
}

National Cancer Institute

\section{Source}

National Cancer Institute. SOX6 wt Allele. NCI Thesaurus. Code C75409.

Human SOX6 wild-type allele is located in the vicinity of $11 \mathrm{p} 15.3$ and is approximately 506 $\mathrm{kb}$ in length. This allele, which encodes transcription factor SOX-6, plays roles in expression of extracellular matrix genes and cell proliferation, and may play roles in oligodendrocyte development, differentiation and migration. Mutations in this gene are associated with craniosynostosis. 